\title{
Racial Difference in the Use of VA Health Services
}

Chichun Fang, Kenneth Langa, Helen Levy, and David Weir

Project \#: UM15-Q2 


\title{
Racial Difference in the Use of VA Health Services
}

\author{
Chichun Fang \\ University of Michigan \\ Kenneth Langa \\ University of Michigan \\ Helen Levy \\ University of Michigan \\ David Weir \\ University of Michigan
}

September 2015

\author{
Michigan Retirement Research Center \\ University of Michigan \\ P.O. Box 1248 \\ Ann Arbor, MI 48104 \\ www.mrrc.isr.umich.edu \\ (734) 615-0422
}

\section{Acknowledgements}

The research reported herein was performed pursuant to a grant from the U.S. Social Security Administration (SSA) funded as part of the Retirement Research Consortium through the University of Michigan Retirement Research Center (5 RRC08098401-07). The opinions and conclusions expressed are solely those of the author(s) and do not represent the opinions or policy of SSA or any agency of the Federal Government. Neither the United States Government or any agency thereof, or any of their employees, makes any warranty, express or implied, or assumes any legal liability or responsibility for the accuracy, completeness, or usefulness of the contents of this report. Reference herein to any specific commercial product, process or service by trade name, trademark, manufacturer, or otherwise does not necessarily constitute or imply endorsement, recommendation or favoring by the United States Government or any agency thereof.

\section{Regents of the University of Michigan}

Michael J. Behm, Grand Blanc; Mark J. Bernstein, Ann Arbor; Laurence B. Deitch, Bloomfield Hills; Shauna Ryder Diggs, Grosse Pointe; Denise Ilitch, Bingham Farms; Andrea Fischer Newman, Ann Arbor; Andrew C. Richner, Grosse Pointe Park; Katherine E. White, Ann Arbor; Mark S. Schlissel, ex officio 


\title{
Racial Difference in the Use of VA Health Services
}

\begin{abstract}
We study the factors that affect the utilization of health care services administered by the Department of Veterans Affairs (VA) and its racial differences. Due to data limitation, previous research in this regard mostly only focuses on veterans who are VA users or at least eligible for VA services. We fill in the gap in literature with a random sample of veterans 51 and older from the Health and Retirement Study. We find that, among all veterans, those who are black and less healthy are more likely to use VA health services. These factors, nevertheless, are no longer statistically significant after the sample is restricted to veterans who are eligible for VA services. We also find that VA health services and services provided through other channels are at least partial substitutes: VA usage drops when a veteran becomes age eligible for Medicare or when a veteran has health insurance coverage through employment. This drop in usage holds not only among all veterans, but also among veterans eligible for VA services. Finally, perception about the quality of services delivered in VA versus non-VA facilities strongly predicts VA services usage. Those who have favorable views toward VA use VA services more, and the results from variance decomposition suggests a majority part of the racial difference in VA usage can be attributed to the racial difference in such perception.
\end{abstract}

\section{Citation}

Fang, Chichun, Kenneth Langa, Helen Levy, and David Weir. 2015. "Racial Difference in the Use of VA Health Services.” Ann Arbor, MI. University of Michigan Retirement Research Center (MRRC) Working Paper, WP 2015-334.

http://www.mrrc.isr.umich.edu/publications/papers/pdf/wp334.pdf

\section{Authors' acknowledgements}

This study is funded by the Social Security Administration through the Michigan Retirement Research Center (UM15-Q2). The Health and Retirement Study is sponsored by the National Institute on Aging (NIA U01AG009740) and is conducted by the University of Michigan. The authors would like to thank the participants in the Michigan Retirement Research Center workshop for the helpful comments. Address correspondence to Chichun Fang, PhD, Institute for Social Research, University of Michigan; Address: 426 Thompson Street, Ann Arbor, MI 48104; E-Mail: chichunf@umich.edu. Kenneth Langa, M.D., PhD; Helen Levy, PhD; and David Weir, $\mathrm{PhD}$; are with the Institute for Social Research, University of Michigan. 


\section{BACKGROUND}

The veterans' health-care system administered by the Department of Veterans Affairs (VA) was established at the end of World War I in order to provide veterans access to medical care and rehabilitation for service-related health conditions (Kizer \& Dudley, 2009). Since then, the VA system has grown to become the largest health-care system in the United States, and plays a role of safety net that provides affordable health care to veterans with low-income and/or service-related disability (Congressional Budget Office, 2009). As of fiscal year 2014, about 6.6 million unique patients are treated in the VA facilities annually; jointly, the total patient expenditure at VA facilities reaches $\$ 58$ billion. $^{1}$

Following VA health-care system’s transformation in the late 1990s, there have been several studies examining the quality of services delivered in VA facilities. The findings from these studies are mixed. Some of them show significant improvement in quality of services delivered and clinical performance, satisfaction, as well as operation efficiency (see Kizer \& Dudley, 2009 for a detailed review of this literature). Others, nevertheless, show that such improvement may not be universal across all facilities and patients. For example, there could be adverse outcomes when the services delivered in VA and non-VA facilities are not coordinated (Asch et al., 2004; Wolinsky, An, Liu, Miller, \& Rosenthal, 2007; Wolinsky et al., 2006). Besides, despite the improvement in procedural measures (Jha, Perlin, Kizer, \& Dudley, 2003), there still is a racial gap in clinical outcomes even within a facility (Gao et al., 2011; Trivedi, Grebla, Wright, \& Washington, 2011), albeit the minority isn’t always disadvantaged (Volpp et al., 2007). Male and minority patients in VA hospitals also tend to have more positive experiences than female and white veterans (Hausmann, Gao, Mor, Schaefer, \& Fine, 2014).

\footnotetext{
${ }^{1}$ National Center for Veterans Analysis and Statistics; http://www.va.gov/vetdata/docs/pocketcards/fy2015q4.pdf
} 
On the other hand, the demand for VA health services is not as widely studied. Factors such as demographics (Hausmann et al., 2014; Liu, Maciejewski, \& Sales, 2005), private health insurance coverage (Shen, Hendricks, Wang, Gardner, \& Kazis, 2008), and Medicare eligibility (Carey et al., 2008; Hynes et al., 2007; Liu et al., 2010; Liu et al., 2011) have been examined. Overall, these studies show that veterans who are younger, white, or covered in private health insurance plans are less likely to use VA services. For veterans who are dual-entitled for VA services and Medicare, VA patients rely more on Medicare for primary care and specialty care, but rely on VA for mental health care.

The most commonly used data sources in the literature of VA utilization are patients and medical records in VA facilities, administrative data from VA and/or Medicare claims, VA enrollees, or some combination of these. One major limitation is that veterans who are not eligible for free or reduced-cost services are likely to be missed if they choose not to "buy in" to VA health services. ${ }^{2}$ Additionally, while these data tend to have rich information in health status and medical history, by nature they are less informative about the experiences of veterans outside hospitals or the comparison between veterans and nonveterans. Consequently, missing from the VA utilization literature are examinations of the differences between VA users and nonusers, and whether those differences affect utilization.

Relying on a more extensive data set, our paper fills this gap in literature. We use data from the Health and Retirement Study (HRS), which follows a representative sample of the elderly (51 and older) population in the U.S. over time. The HRS allows us to compare not only VA users versus nonusers, but also veterans versus nonveterans in the overall population. Its longitudinal nature provides extensive information on education, earnings, job history, and other

\footnotetext{
${ }^{2}$ Although the qualification to receive free (or reduced copayment) VA health services is jointly determined by service-related disability rating and income, veterans who are not automatically qualified based on disability rating and income can still pay the full price to receive care in VA facilities if they so choose .
} 
demographic and psychosocial information (detailed in the next section) that is usually not available in other data sources. In 2011 and 2013, the HRS also administered veteran mail surveys that ask veterans about their health status, experiences in the military, and perception about the quality of services delivered in VA facilities.

Three research questions are addressed in this study. Is there a racial difference in the use of VA health services? What economic, health, social, or attitudinal factors influence such use? Do these factors explain the racial differences observed? The answers to these questions are of interest for a number of policy concerns, such as understanding the demand for health care services in the VA system, assessing the perception of the quality of services delivered, and gauging the interaction of the VA system with other changes affecting the health care environment such as expansion or contraction in Medicaid, Medicare, and subsidies under the Affordable Care Act (ACA). Finally, since the older veterans are dual eligible for services from VA and Medicare, the demand for VA services also has ramifications regarding the allocation of government resources in the health care system.

We find that veterans are less likely to work for pay and less healthy than the general population in the same age cohort. Consistent with earlier studies (for example, Liu et al., 2005; Washington, Villa, Brown, Damron-Rodriguez, \& Harada, 2005), we also find black veterans are more likely to use VA services than whites. Among veterans who are eligible for VA services, those who are Medicare eligible (65 and older) or those who have health insurance coverage through employment (regardless if own or spousal coverage), are more likely to be VA users. We also show that the observed racial difference in VA services usage is largely attributed to the racial difference in the attitudes toward the quality of services delivered in VA facilities. 
In the next section, the HRS data and research methods used in this study are introduced. After we present our results, we conclude the paper with a discussion of policy implications and suggestions for future research.

\section{METHODS}

\section{Data Sources}

We use the Health and Retirement Study, a panel study of a nationally representative sample of people 51 and older in the U.S. The information on health status and health insurance coverage is provided in the 2012 core survey, from which we are able to tell a respondent's selfreported health status as well as existing diseases, whether a respondent is eligible for VA health services, whether the respondent used such services during the 12-month period prior to the interview, and whether the respondent is covered by other health insurance plans. We also collect key demographic information, such as age, race, gender, marital status, level of education, labor force participation, and income, from the core survey. Finally, from the 2012 core survey, we construct an indicator for cognitive impairment without dementia (Crimmins, Kim, Langa, \& Weir, 2011), which is a dummy variable that indicates whether the respondent is cognitively impaired.

The HRS administered off-year surveys in 2011 and 2013. The 2011 mail survey was administered to a random sample of all HRS respondents and had a section for veterans on experiences regarding the VA system. The 2013 mail survey was administered to those who self-reported as veterans only. The mail survey provides information regarding type(s) of services used, as well as the perception about the quality of VA health care services. 
Respondents can answer VA services are better (than non-VA services), non-VA services are better, or neutral.

Overall, 3,544 respondents self-identified themselves as veterans in the 2012 core survey. Roughly 70\% (2,422) of these participants also participated in the off-year mail surveys in 2011 and/or 2013. Slightly more than half $(1,269)$ of these veterans are eligible for VA services, and 701 of them reported to have used VA health services in the 12-month period prior to the survey. Due to missing data, the numbers of observations used in the regression analysis could be lower and are reported the corresponding tables.

\section{Empirical Model}

In addition to logit regressions, we use the decomposition method proposed in Fairlie (2005) to calibrate how much of the racial differences in VA health services usage can be attributed to the racial differences in the attitudes toward VA services. This method is similar to Oaxaca (1973) and Blinder (1973) in its nature, but is modified to accommodate nonlinear models. Namely, the racial differences in VA usage can be decomposed into two components: one that can be attributed to the racial differences in the distributions of observable characteristics in the regression, and the other that is attributed to the coefficients in the regression. In Fortin, Lemieux, and Firpo (2011), the former is called the "compositional effect," while the latter is called the "wage structure effect" as the decomposition method was initially developed to analyze wage gap. In this paper, we will simply call this latter component "structure effect” to avoid confusion.

More specifically, let $N$ be the sample size, $X_{i}$ be an array of respondent $i$ 's characteristics, and $\hat{\beta}$ be the coefficients associated with $X_{i}$ in a function $F$ that determines 
whether a respondent uses VA health services or not. Hence, mean level of VA usage in the population, $\bar{U}$, can be written as:

$$
\bar{U}=\sum_{i=1}^{N} \frac{F\left(X_{i} \widehat{\beta}\right)}{N}
$$

It follows that the racial usage difference can be written as (the superscript $B$ and $W$ stand for black and white, respectively):

$$
\bar{U}^{W}-\bar{U}^{B}=\sum_{i=1}^{N^{W}} \frac{F\left(X_{i}^{W} \widehat{\beta}^{W}\right)}{N^{W}}-\sum_{i=1}^{N^{B}} \frac{F\left(X_{i}^{B} \widehat{\beta}^{B}\right)}{N^{B}}
$$

Note that while $\hat{\beta}$ is the coefficient from the "pooled" (black and white) model, $\hat{\beta}^{W}$ and $\hat{\beta}^{B}$ are coefficients from regressions using white- and black-only observations, respectively.

Subtracting and adding the term $\sum_{i=1}^{N^{B}} \frac{F\left(X_{i}^{B} \widehat{\beta}^{W}\right)}{N^{B}}$, we get:

$$
\bar{U}^{W}-\bar{U}^{B}=\left[\sum_{i=1}^{N^{W}} \frac{F\left(x_{i}^{W} \widehat{\beta}^{W}\right)}{N^{W}}-\sum_{i=1}^{N^{B}} \frac{F\left(x_{i}^{B} \widehat{\beta}^{W}\right)}{N^{B}}\right]+\left[\sum_{i=1}^{N^{B}} \frac{F\left(x_{i}^{B} \widehat{\beta}^{W}\right)}{N^{B}}-\sum_{i=1}^{N^{B}} \frac{F\left(x_{i}^{B} \widehat{\beta}^{B}\right)}{N^{B}}\right]
$$

If the function $F(\cdot)$ is linear, this becomes the standard Oaxaca-Blinder decomposition (Blinder, 1973; Fortin et al., 2011; Oaxaca, 1973):

$$
\bar{U}^{W}-\bar{U}^{B}=\left[\left(\bar{X}^{W}-\bar{X}^{B}\right) \hat{\beta}^{W}\right]-\left[\bar{X}^{B}\left(\hat{\beta}^{W}-\hat{\beta}^{B}\right)\right]
$$

In this equation, the first bracket is the "compositional effect" (the racial gap in VA services usage that can be attributed to the racial difference in the distributions of observable characteristics), and the second bracket is the "structure effect" (the racial usage gap that can be attributed to the racial differences in coefficients).

When the function $F(\cdot)$ is not linear, however, equation [3] may not lead to equation [4]. Consider first a case where the sample sizes of blacks and whites are the same, that is, $N^{B}=$ $N^{W}=N$. Let $X_{j}(j=1,2, \ldots, J)$ be the $j^{\text {th }}$ item in the array of $X$ and $X_{-j}$ be all other variables in $X$ except $X_{j}$, the compositional effect (the terms in the first bracket in equation [3]) can be written as: 


$$
\sum_{j=1}^{J}\left[\frac{1}{N} \sum_{i=1}^{N}\left(F\left(X_{j i}^{W} \hat{\beta}_{j}^{W}+X_{-j i}^{W} \hat{\beta}_{-j}^{W}\right)-F\left(X_{j i}^{B} \hat{\beta}_{j}^{W}+X_{-j i}^{W} \hat{\beta}_{-j}^{W}\right)\right)\right]
$$

In other words, the compositional effect of the racial gap in VA care usage that is attributed to $X_{j}$, $\widehat{D}_{j}$, is:

$$
\widehat{D}_{j}=\frac{1}{N} \sum_{i=1}^{N}\left(F\left(X_{j i}^{W} \hat{\beta}_{j}^{W}+X_{-j i}^{W} \hat{\beta}_{-j}^{W}\right)-F\left(X_{j i}^{B} \hat{\beta}_{j}^{W}+X_{-j i}^{W} \hat{\beta}_{-j}^{W}\right)\right)
$$

The variance of $\widehat{D}_{j}$ can be approximated using the Delta method (Fairlie, 2005; Oaxaca \& Ransom, 1994).

Equation [6] provides the method to estimate the compositional effect when the underlying function $F(\cdot)$ is not linear. More generally, when the sample sizes of the two groups are not the same (as in our data, there are many more white than black veterans), we instead have a bootstrap estimate of $\widehat{D}_{j}$. In each iteration of the bootstrap, equation [6] is estimated with a random sample of white veterans and all black veterans so that the two groups have the same number of observations. Hence, $\hat{\beta}_{j}^{W}$ and $\hat{\beta}_{-j}^{W}$ are different in each iteration, as the white-only regression is re-estimated with a different random sample of white veterans. In this paper, the estimate of $\widehat{D}_{j}$ is obtained through 1,000 bootstrap iterations.

\section{RESULTS}

\section{Characteristics of the VA Users}

Descriptive statistics of selected variables are listed in Table 1, with various sample restrictions in each column. All variables in Table 1 except age and household income are dummy variables. Note that the three variables under the "other insurance" category: employersponsored health insurance, Medicare, and Medicaid are not mutually exclusive. 
The first two columns in Table 1 compare all mail survey respondents ${ }^{3}$ and veterans in the survey. Compared to the U.S. population 51 and older, veterans, on average, are more likely to be male, slightly older, less likely to work for pay, and have lower household income. Veterans are also likely to be covered by Medicare, which reflects veterans being older than the average population.

Columns 3 and 4 compare veterans ineligible for VA services versus those who are eligible, columns 5 and 6 compare the eligible veterans who do not use VA services versus the users, and columns 7 and 8 compare the veterans who use VA services only versus those who use VA and other services. A few patterns emerge from these comparisons.

Veterans who are black are more likely to be eligible for VA. Conditional on being eligible, they are more likely to be users. Conditional on being users, they are also more likely to rely on VA only for health care services. Veterans who are not married are also more likely to be eligible, more likely to be users conditional on being eligible, and use VA only conditional on being users. The other two variables that show clear patterns are related: whether a veteran is working for pay and whether s/he has employer-sponsored health insurance plan (through own employment or spousal coverage). Those who are not working for pay and hence do not have employer-sponsored health insurance plans are more likely to be eligible for VA and more likely to be users.

The relationship between age and demand for VA services is likely nonlinear. Health status is usually negatively correlated with age, so the demand for health care should increase with age. However, as veterans become eligible for Medicare at age 65, the demand for VA

\footnotetext{
${ }^{3}$ The HRS administered the 2011 mail survey to a random sample of the HRS respondents, and the questions regarding VA services are in a section which only veterans are required to answer. Although we only focus on the information pertaining to VA services in this study, the mail survey as well as the core HRS survey allow us to compare veterans against the whole populations in key demographic, social economic, and health variables.
} 
services may not necessarily increase with age even though the demand for health care increases. In Figure 1 we plot the likelihood of using VA health services by age. It is clear that VA usage increases roughly until HRS veterans become eligible for Medicare at age 65. Beyond 65, the usage decreases, and the patterns are similar regardless whether we look at VA services as a whole or each type of VA services surveyed in the HRS (inpatient care, outpatient care, prescriptions, and emergency care). The discontinuity in utilization at age 65, hence, is not as evident as the results reported in Card, Dobkin, and Maestas (2008), which does not include VA hospitals. Due to the nonlinearity, we use a set of age group dummy variables in the following analysis.

\section{Determinants of VA Services Usage}

Tables 2A through Tables 3C are the parametric versions of Table 1 using logit regressions. In Tables $2 \mathrm{~A}$ and $2 \mathrm{~B}$, the dependent variable is a dummy variable that equals one if a veteran is a VA user. In Tables 3A through 3C, the dependent variable is a dummy indicating that a veteran uses VA services only.

Table 2A estimates the likelihood of VA usage among all veterans. It shows that black veterans are more likely to use VA services. The coefficient 0.6230 in Column 5 translates to black veterans $86 \%$ more likely to be users (odds ratio equals to 1.8646 ). Veterans who are between 60 and 64 are most likely to be users among all age groups, and those who are between 65 and 69 and between 70 and 74 are only 30\% as likely to be users (coefficients of -1.1135 and -1.1576 in Column 5 correspond to odds ratios of 0.3283 and 0.3142 , respectively). Veterans who do not have a high school degree are also more likely to use VA (odds ratio equal to 1.4276). Health care services received through employer-sponsored health insurance and Medicaid have significantly negative results on VA usage: The negative coefficients -1.0155 and -1.1948 
correspond to odds ratios of 0.3621 and 0.3032 , suggesting a $65 \%$ to $70 \%$ decline in the likelihood of VA usage compared to those with no other insurance coverage. Not surprisingly, veterans who are in worse health conditions are more likely to be VA users as they likely have higher demand for health care.

Table 2B restricts the sample to the veterans who report to be eligible for VA services. Many of the significant coefficients in Column 5 of Table 2A become insignificant, suggesting that some factors affecting VA usage are correlated with eligibility. For example, since VA eligibility is determined by health status and income, VA eligibility is likely to be correlated with self-reported health and Medicaid eligibility. Table 2B still shows a drop in the likelihood of VA usage at 65 and older compared to those at age 60-64. Veterans who have employer-sponsored health insurance are also less likely to use VA services conditional on being eligible. Jointly, these results suggest that services delivered through other channels are at least partial substitutes of VA health services.

Table 3A examines, among all veterans, those who use VA services only. The results are qualitatively similar to Table 2A. Similarly, results in Table 3B and Table 2B are qualitatively similar. Finally, Table 3C compares, among VA users, those who only use VA against those who use VA and other services. In the full model (Column 5), none of the coefficients is statistically significant at 5\% level.

To summarize the results from Table 2A through Table 3C, we find that among all veterans, black and less healthy veterans are more likely to be VA users. However, conditional on being eligible, race and health status are no longer strong predictors of VA services usage. We do find that age and availability of other health insurance coverage affect VA usage. More specifically, there is a significant drop in usage before and after age 65: There is also a 
significant drop in usage when a veteran has employer-sponsored health insurance coverage. The drop in the likelihood is about 70\% (odds ratio at about 0.3 ), and such a big decline in usage suggests substitution between serviced delivered in VA facilities and through other channels.

\section{Attitudes toward VA Services and Racial Difference in VA Services Usage}

A unique provision in the HRS is the questions regarding the perceptions of service quality delivered in VA versus non-VA facilities. As we show below, although perception is subjective by nature, such perception is an important factor in explaining VA service usage, as well as the racial usage gap.

Numbers in Tables 4 and 5 show the correlations between VA service usage and perceptions about those services. Comparing to nonusers, VA users tend to think VA services are better than non-VA services. Among nonusers, the perceptions about VA versus non-VA services are similar between those who are eligible for VA and those who are not. The veterans who are eligible and actually use VA have more favorable views about VA services. Table 5 further restricts the sample to VA users only and compares the attitudes between those who only use VA and those who use both VA and non-VA services. We find that veterans who use VA services only have much more favorable views about VA with a sizable margin. Table 6 splits the numbers in Table 5 by race. The patterns in Table 5 hold for both white and black veterans in Table 6; furthermore, black veterans are more likely to think that the qualities of services delivered in VA facilities are better.

Table 7A presents a parametric analysis of how the attitude toward VA services quality affects usage among all veterans. The first column in Table 7A is essentially the last column in 
Table 2A plus the perception/attitudinal variables on the right hand side. ${ }^{4}$ The coefficients largely follow the same pattern, except that the coefficient on black is no longer statistically significant. The newly-added variables in Table 7A, however, are highly significant, indicating that the perception about the quality of VA services strongly affects the likelihood of VA health services usage.

Given the different distributions of perception about VA services between black and white veterans shown in Table 6, we next investigate how much of the racial difference in VA service usage can be attributed to the racial difference in attitudinal factors using the variance decomposition method introduced in the previous section. The second and third columns in Table 7 re-estimate the model by race, which provide the information necessary to estimate equations [5] and [6]. The variance decomposition method allows us to decompose the racial gap in VA health services usage into the "compositional effect” (part of the gap that can be attributed to the racial difference in the distributions of characteristics observable to researchers) and the "structure effect" (the part that is attributed to the racial difference in "returns" to, i.e. coefficients associated with these characteristics in a parametric model). Our empirical strategy is justified by a comparison between the second and third columns, as coefficients do differ by race when the models are separately estimated.

To facilitate the decomposition based on equations [5] and [6], we group the explanatory variables into several categories: gender, age (in categories of 50-54, 55-59, 60-64, 65-69, 70-74, and 75+), marital status (married, partnered, separated/divided, widowed, and never married), education (less than high school, high school, some college, and college and above), work and income (working for pay or not and household income), health (self-report of health and the

\footnotetext{
${ }^{4}$ Note that numbers of observations are different in Table 2A and Table7A due to the missing data in perception measures. Same conclusion can still be made if Table 2A is re-estimated with the same subsample used in Table 7A.
} 
dummy indicating cognitively impaired or dementia), availability of other insurance coverage (dummy variables indicating whether the respondent has Medicare, Medicaid, and employersponsored health insurance coverage), and attitudes toward the quality of VA services (VA services are better, non-VA services are better, or neutral). The results of variance decomposition are shown in Table 7B.

The first row in Table 7B is the unconditional racial difference in VA health services usage and is about $10 \%$. The next two rows show that, among the $10 \%$ difference in usage, the structure effect is $5.65 \%$ and the compositional effect is $4.38 \%$. The remaining rows break down the compositional effect that can be attributed to each category of observable variables. Only the numbers in last two rows are statistically significant. The number of 0.0058 on "health" means that, had the black veterans had the same distribution of health conditions as white veterans, the racial difference in VA usage would be $0.58 \%$ smaller. In other words, $0.58 \%$ of the racial difference in VA health service usage can be attributed to the racial difference in health conditions. It is clear in the last row that the racial difference in perception about the quality of VA services plays a big role in the racial difference in VA usage: Had the distribution of perceptions been the same between black and white veterans, the racial difference in usage would be cut by almost half. Since black veterans are more likely to think VA services are better than non-VA services (Table 6), half of the racial difference in usage can be attributed to black veterans having more favorable attitudes toward VA services.

Tables 8A and 8B repeat the same estimation with those who are eligible for VA services only. Table 8A, hence, is comparable to Table 2B. Again, the last few rows in Table 8A suggest that perception about service quality strongly affect usage among eligible veterans. Table 8B shows that, among veterans eligible for VA services, the whole racial gap in usage can be 
attributed to racial difference in the perception about quality of services delivered in VA versus non-VA facilities.

To summarize our results, in Tables 2A through 3B we show that, among all veterans, those who are black and less healthy are more likely to be VA users. Nevertheless, race and health status are no longer significant explanatory variables once the sample is conditional on eligibility for VA services. Among either all veterans or only those eligible for VA services, the likelihood of VA services usage drops at age 65 as well as for veterans who obtain health insurance coverage through employment. Both suggest that VA services are at least partially substituted by services provided through Medicare or employer-sponsored health insurance coverage. In Tables 4 through 6 , we show that the attitudes toward quality of VA services differ by race and are strongly correlated with usage. The numbers in Tables 7A through $8 \mathrm{~B}$ imply that a majority portion of racial difference in VA usage can be attributed to the racial difference in the attitudes toward the quality of VA services.

\section{CONCLUSIONS}

Using a random sample of U.S. veterans older than 51 years old in the Health and Retirement Study, we show that veterans who are black and less healthy are more likely to use VA services, although the effects of race and health and health status on usage are no longer observed conditional on eligibility for VA. More importantly, veterans who are 65 and older or who have health insurance coverage through employment are less likely to use VA services: Conditional on usage, these veterans are also less likely to rely on VA services only for health care. Older than 65 and having health insurance coverage through employment each reduces the likelihood of using VA services by 70\%, suggesting at least partial substitutions between health care services provide by VA and through other channels. 
We also find that a sizable portion of racial difference in the usage of VA services can be attributed to the black-white difference in perceptions about the quality of services delivered in VA versus non-VA facilities. Namely, veterans who have favorable views about VA are more likely to use VA services, and black veterans, on average, have more favorable views than their white peers. Had black and white veterans had the same distributions of attitudes toward VA quality, the racial gap in usage would have been cut in half among all veterans and virtually eliminated among those who are eligible for VA services.

Our study fills a gap in the literature of VA services utilization by using a random sample of veterans that include both VA users and nonusers. In most of the previous studies, nonusers are never observed due to data limitation. The Health and Retirement Study not only allows us to assess the factors influencing utilization by comparing users versus nonusers, but also provides extensive information beyond medical records not usually available in the previous literature.

Our findings have important policy implications regarding the role of the VA system under the ACA. Our finding that the demand for VA services is at least partially substituted by services delivered through other channels is informative regarding the demand for care in multiple sectors of the health care system. Preference is revealed when veterans choose which facility to receive health services from. And veterans choose non-VA over VA facilities either because non-VA services are preferred or because they are not able to get services in VA facilities. Regardless of the reason, it suggests potential to improve the efficiency of the way health services are delivered. As health insurance coverage expands under the ACA, the likelihood of potential substitution between VA and non-VA services should increase. Such 
potential substitution may have significant consequences on the demand for VA services, as well as the type of patients who seek health care in VA facilities.

Future studies should also focus on the antecedents of the racial difference in attitudes toward the VA. Do veterans establish their attitudes toward VA services through their fellow veterans or through their own experience in VA facilities? The answer to this question is one of the keys to addressing the racial disparity in perception.

Another related issue that requires further examination is causality: Does a more favorable view toward VA services include the usage of VA services? We are not able to answer this question in our data because we do not have within-individual variation in the perception measure. The causality issue is likely complicated by one of our findings that Medicare and VA services are at least partially substitutes: VA services usage drops at the age of Medicare eligibility regardless what the perception is. Hence, to address the causality issue, it requires data that facilitates the identification of interactions among the effects influencing VA services and the substitution between services delivered in VA facilities and other channels. 


\section{REFERENCES}

Asch, Steven M., McGlynn, Elizabeth A., Hogan, Mary M., Hayward, Rodney A., Shekelle, Paul, Rubenstein, Lisa, . . Kerr, Eve A. (2004). Comparison of Quality of Care for Patients in the Veterans Health Administration and Patients in a National Sample. Annals of Internal Medicine, 141(12), 938-945.

Blinder, Alan S. (1973). Wage Discrimination: Reduced Form and Structural Estimates Journal of Human Resources, 8(4), 436-455.

Card, David, Dobkin, Carlos, \& Maestas, Nicole. (2008). The Impact of Nearly Universal Insurance Coverage on Health Care Utilization: Evidence from Medicare. American Economic Review, 98(5), 2242-2258.

Carey, Kathleen, Montez-Rath, Maria E., Rosen, Amy K., Christiansen, Cindy L., Loveland, Susan, \& Ettner, Susan L. (2008). Use of VA and Medicare Services by Dually Eligible Veterans with Psychiatric Problems. Health Services Research, 43(4), 1164-1183.

Congressional Budget Office. (2009). Quality Initiatives Undertaken by the Veterans Health Administration.

Crimmins, Eileen M., Kim, Jung Ki, Langa, Kenneth M., \& Weir, David R. (2011). Assessment of Cognition Using Surveys and Neuropsychological Assessment: The Health and Retirement Study and the Aging, Demographics, and Memory Study. The Journals of Gerontology, Series B: Psychological Sciences and Social Sciences, 66B(S1), i162-i171.

Fairlie, Robert W. (2005). An Extension of the Blinder-Oaxaca Decomposition Technique to Logit and Probit Models. Journal of Economic and Social Measurement, 30(4), 305-316.

Fortin, Nicole, Lemieux, Thomas, \& Firpo, Sergio. (2011). Decomposition Methods in Economics. In O. Ashenfelter \& D. Card (Eds.), Handbook of Labor Economics (Vol. 4, pp. 1-102). Netherlands: Elsevier.

Gao, Jian, Moran, Eileen, Almenoff, Peter L., Render, Marta L., Campbell, James, \& Jha, Ashish K. (2011). Variations In Efficiency And The Relationship To Quality Of Care In The Veterans Health System Health Affairs, 30(4), 665-663.

Hausmann, Leslie R. M., Gao, Shasha, Mor, Maria K., Schaefer, James H. Jr., \& Fine, Michael J. (2014). Patterns of Sex and Racial/Ethnic Differences in Patient Health Care Experiences in US Veterans Affairs Hospitals. Medical Care, 52(4), 328-335.

Hynes, Denise M., Koelling, Kristin, Stroupe, Kevin, Arnold, Noreen, Mallin, Katherine, Sohn, MinWoong, ... Kok, Linda. (2007). Veterans' Access to and Use of Medicare and Veterans Affairs Health Care. Medical Care, 45(3), 214-223.

Jha, Ashish K., Perlin, Jonathan B., Kizer, Kenneth W., \& Dudley, R. Adams. (2003). Effect of the Transformation of the Veterans Affairs Health Care System on the Quality of Care. New England Journal of Medicine, 348(22), 2218-2217.

Kizer, Kenneth W., \& Dudley, R. Adams. (2009). Extreme Makeover: Transformation of the Veterans Health Care System. Annual Review of Public Health, 30, 313-339.

Liu, Chuan-Fen, Chapko, Michael, Bryson, Chris L., Burgess Jr., James F., Fortney, John C., Perkins, Mark, ... Maciejewski, Matthew L. (2010). Use of Outpatient Care in Veterans Health Administration and Medicare among Veterans Receiving Primary Care in Community-Based and Hospital Outpatient Clinics. Health Services Research, 45(5), 1268-1286.

Liu, Chuan-Fen, Maciejewski, Matthew L., \& Sales, Anne E. B. (2005). Changes in Characteristics of Veterans Using the VHA Health Care System between 1996 and 1999. Health Research Policy and Systems, 3(5), 1-7. 
Liu, Chuan-Fen, Manning, Willard G., Burgess, James F. Jr, Herbert, Paul L., Bryson, Chris L., Fortney, John, ... Maciejewski, Matthew L. (2011). Reliance on Veterans Affairs Outpatient Care by Medicare-eligible Veterans. Medical Care, 49(10), 911-917.

Oaxaca, Ronald L. (1973). Male-Female Wage Differentials in Urban Labor Markets. International Economic Review, 14(3), 693-709.

Oaxaca, Ronald L., \& Ransom, Michael R. (1994). On Discrimination and the Decomposition of Wage Differentials. Journal of Econometrics, 61(1), 5-21.

Shen, Yujing, Hendricks, Ann, Wang, Fenghua, Gardner, John, \& Kazis, Lewis E. (2008). The Impact of Private Insurance Coverage on Veterans' Use of VA Care: Insurance and Selection Effects. Health Services Research, 43(1), 267-286.

Trivedi, Amal N., Grebla, Regina C., Wright, Steven M., \& Washington, Donna L. (2011). Despite Improved Quality Of Care In The Veterans Affairs Health System, Racial Disparity Persists For Important Clinical Outcomes Health Affairs, 30(4), 707-715.

Volpp, Kevin G., Stone, Roslyn, Lave, Judith R., Jha, Ashish K., Pauly, Mark, Klusaritz, Heather, ... Polsky, Daniel. (2007). Is Thirty-Day Hospital Mortality Really Lower for Black Veterans Compared with White Veterans? Health Services Research, 42(4), 1613-1631.

Washington, Donna L., Villa, Valentine, Brown, Arleen, Damron-Rodriguez, JoAnn, \& Harada, Nancy. (2005). Racial/Ethnic Variations in Veterans' Ambulatory Care Use. American Journal of Public Health, 95(12), 2231-2237.

Wolinsky, Fredric D., An, Hyonggin, Liu, Li, Miller, Thomas R., \& Rosenthal, Gary E. (2007). Exploring the Association of Dual Use of the VHA and Medicare with Mortality: Separating the Contributions of Inpatient and Outpatient Services. BMC Health Services Research, 7(70), 1-10.

Wolinsky, Fredric D., Miller, Thomas R., An, Hyonggin, Brezinski, Paul R., Vaughn, Thomas E., \& Rosenthal, Gary E. (2006). Dual Use of Medicare and the Veterans Health Administration: Are There Adverse Health Outcomes? BMC Health Services Research, 6(131), 1-11. 
Figure 1: Use of VA Health Services, by Age and Race

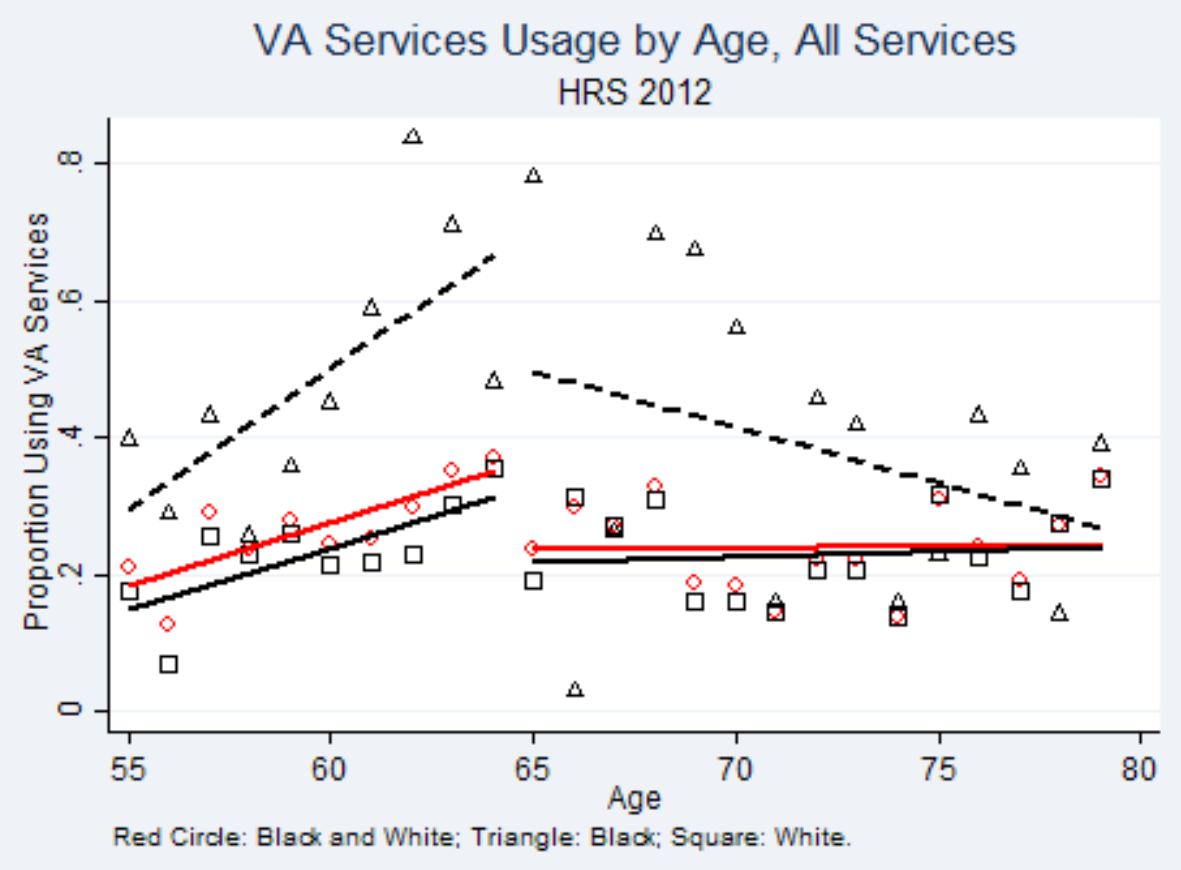


Table 1: Characteristics of HRS Mail Survey Respondents

\begin{tabular}{|c|c|c|c|c|c|c|c|c|}
\hline & \multirow{4}{*}{$\begin{array}{c}\text { Full } \\
\text { Sample }\end{array}$} & \multicolumn{6}{|c|}{ Veterans } & \\
\hline & & \multirow{3}{*}{$\begin{array}{c}\text { All } \\
\text { Veterans }\end{array}$} & \multirow{3}{*}{$\begin{array}{l}\text { Ineligible } \\
\text { for VA }\end{array}$} & \multicolumn{5}{|c|}{ Eligible for VA } \\
\hline & & & & \multirow{3}{*}{$\begin{array}{l}\text { All } \\
\text { [4] }\end{array}$} & \multirow{3}{*}{$\begin{array}{c}\text { Non-User } \\
\text { [5] }\end{array}$} & \multicolumn{3}{|c|}{ VA User } \\
\hline & & & & & & All & VA Only & $\begin{array}{l}\text { VA and } \\
\text { Non-VA }\end{array}$ \\
\hline & {$[1]$} & {$[2]$} & [3] & & & {$[6]$} & [7] & [8] \\
\hline \multicolumn{9}{|l|}{ Demography } \\
\hline White & 0.8677 & 0.8965 & 0.9242 & 0.8697 & 0.8806 & 0.8604 & 0.7931 & 0.8950 \\
\hline Black & 0.0771 & 0.0674 & 0.0408 & 0.0932 & 0.0732 & 0.1105 & 0.1619 & 0.0839 \\
\hline Other Race & 0.0541 & 0.0357 & 0.0348 & 0.0366 & 0.0460 & 0.0285 & 0.0432 & 0.0209 \\
\hline Female & 0.4803 & 0.0396 & 0.0502 & 0.0294 & 0.0270 & 0.0314 & 0.0360 & 0.0291 \\
\hline Age & 65.391 & 69.602 & 69.382 & 69.815 & 70.111 & 69.559 & 66.069 & 71.357 \\
\hline \multicolumn{9}{|l|}{ Marital Status } \\
\hline Married & 0.6735 & 0.7091 & 0.7469 & 0.6724 & 0.7190 & 0.6324 & 0.4745 & 0.7137 \\
\hline \multicolumn{9}{|l|}{ Education } \\
\hline Less than High School & 0.1371 & 0.1039 & 0.0908 & 0.1165 & 0.0845 & 0.1441 & 0.1307 & 0.1510 \\
\hline \multicolumn{9}{|l|}{ Work and Income } \\
\hline Work for Pay & 0.4488 & 0.3631 & 0.4083 & 0.3191 & 0.3902 & 0.2576 & 0.2457 & 0.2590 \\
\hline HH Income (2012 USD\$) & 77,080 & 69,538 & 77,832 & 61,505 & 71,180 & 53,164 & 40,752 & 59,561 \\
\hline \multicolumn{9}{|l|}{ Other Insurance } \\
\hline Employer-Sponsored HI & 0.5069 & 0.4115 & 0.4791 & 0.3460 & 0.4752 & 0.2345 & 0.1347 & 0.2860 \\
\hline Medicare & 0.5001 & 0.6828 & 0.6868 & 0.6726 & 0.6664 & 0.6780 & 0.5382 & 0.7501 \\
\hline Medicaid & 0.0503 & 0.0319 & 0.0394 & 0.0241 & 0.0211 & 0.0266 & 0.0217 & 0.0292 \\
\hline \multicolumn{9}{|l|}{ Self-Reported Health } \\
\hline Fair or Poor & 0.2303 & 0.2476 & 0.2063 & 0.2877 & 0.1829 & 0.3780 & 0.3705 & 0.3819 \\
\hline Number of Observations & 8,262 & 2,422 & 1,153 & 1,269 & 568 & 701 & 221 & 480 \\
\hline
\end{tabular}


Table 2A: Likelihood of VA Services Usage, All Veterans

\begin{tabular}{|c|c|c|c|c|c|}
\hline \multirow[b]{2}{*}{ Dependent Variables } & \multicolumn{5}{|c|}{$\begin{array}{l}\text { Dependent variable=1 if the respondent is a VA user. } \\
\text { Coefficients on Logit Models }\end{array}$} \\
\hline & [1] & [2] & [3] & [4] & [5] \\
\hline \multicolumn{6}{|l|}{ Race and Gender } \\
\hline Black & $\begin{array}{c}0.7265^{* *} \\
(0.1290)\end{array}$ & $\begin{array}{c}0.6481^{* *} \\
(0.1405)\end{array}$ & $\begin{array}{c}0.6084 * * \\
(0.1423)\end{array}$ & $\begin{array}{c}0.6489 * * \\
(0.1473)\end{array}$ & $\begin{array}{c}0.6230 * * \\
(0.1490)\end{array}$ \\
\hline Female & & $\begin{array}{l}-0.4323 \\
(0.2575)\end{array}$ & $\begin{array}{l}-0.4187 \\
(0.2602)\end{array}$ & $\begin{array}{l}-0.4230 \\
(0.2688)\end{array}$ & $\begin{array}{l}-0.4233 \\
(0.2719)\end{array}$ \\
\hline \multicolumn{6}{|l|}{$\begin{array}{l}\text { Age } \\
\text { (Omitted Group: Age 60-64) }\end{array}$} \\
\hline Age $50-54$ & & $\begin{array}{c}-0.6020^{* *} \\
(0.2658)\end{array}$ & $\begin{array}{l}-0.5018 \\
(0.2700)\end{array}$ & $\begin{array}{c}-0.5651^{* *} \\
(0.2788)\end{array}$ & $\begin{array}{c}-0.6264 * * \\
(0.2832)\end{array}$ \\
\hline Age 55-59 & & $\begin{array}{c}-0.4683 * * \\
(0.2048)\end{array}$ & $\begin{array}{l}-0.4033 \\
(0.2083)\end{array}$ & $\begin{array}{c}-0.4328 * * \\
(0.2162)\end{array}$ & $\begin{array}{c}-0.5087 * * \\
(0.2192)\end{array}$ \\
\hline Age 65-69 & & $\begin{array}{c}-0.7867 * * \\
(0.1930)\end{array}$ & $\begin{array}{c}-0.8624 * * \\
(0.1960)\end{array}$ & $\begin{array}{l}-1.1162 * * \\
(0.2584)\end{array}$ & $\begin{array}{c}-1.1135^{* *} \\
(0.2611)\end{array}$ \\
\hline Age $70-74$ & & $\begin{array}{l}-0.7509 * * \\
(0.1720)\end{array}$ & $\begin{array}{l}-0.8593 * * \\
(0.1765)\end{array}$ & $\begin{array}{l}-0.1913 * * \\
(0.2498)\end{array}$ & $\begin{array}{c}-1.1576^{* *} \\
(0.2523)\end{array}$ \\
\hline Age $75+$ & & $\begin{array}{l}-0.2514 \\
(0.1465)\end{array}$ & $\begin{array}{l}-0.4240 * * \\
(0.1555)\end{array}$ & $\begin{array}{l}-0.7301^{* *} \\
(0.2330)\end{array}$ & $\begin{array}{c}-0.6707 * * \\
(0.2360)\end{array}$ \\
\hline \multicolumn{6}{|l|}{$\begin{array}{l}\text { Marital Status } \\
\text { (Omitted: Never Married) }\end{array}$} \\
\hline Married & & $\begin{array}{l}-0.1862 \\
(0.2854)\end{array}$ & $\begin{array}{l}-0.0996 \\
(0.2934)\end{array}$ & $\begin{array}{l}-0.0037 \\
(0.3012)\end{array}$ & $\begin{array}{l}-0.0592 \\
(0.3054)\end{array}$ \\
\hline Partnered & & $\begin{array}{c}0.2581 \\
(0.3423)\end{array}$ & $\begin{array}{c}0.2525 \\
(0.3504)\end{array}$ & $\begin{array}{c}0.2601 \\
(0.3588)\end{array}$ & $\begin{array}{c}0.1966 \\
(0.3638)\end{array}$ \\
\hline Separated/Divorced & & $\begin{array}{c}0.5074 \\
(0.3105)\end{array}$ & $\begin{array}{c}0.5330 \\
(0.3152)\end{array}$ & $\begin{array}{c}0.5643 \\
(0.3228)\end{array}$ & $\begin{array}{c}0.5279 \\
(0.3270)\end{array}$ \\
\hline Widowed & & $\begin{array}{l}-0.2894 \\
(0.3187)\end{array}$ & $\begin{array}{l}-0.2945 \\
(0.3235)\end{array}$ & $\begin{array}{l}-0.1732 \\
(0.3315)\end{array}$ & $\begin{array}{l}-0.2444 \\
(0.3363)\end{array}$ \\
\hline \multicolumn{6}{|l|}{$\begin{array}{l}\text { Education } \\
\text { (Omitted Group: High School) }\end{array}$} \\
\hline Less than High School & & & $\begin{array}{c}0.4059 * * \\
(0.1532)\end{array}$ & $\begin{array}{c}0.4013 * * \\
(0.1569)\end{array}$ & $\begin{array}{c}0.3560 * * \\
(0.1605)\end{array}$ \\
\hline Some College & & & $\begin{array}{c}0.1737 \\
(0.1236)\end{array}$ & $\begin{array}{c}0.1751 \\
(0.1264)\end{array}$ & $\begin{array}{c}0.1850 \\
(0.1278)\end{array}$ \\
\hline College or More & & & $\begin{array}{l}-0.1883 \\
(0.1262)\end{array}$ & $\begin{array}{l}-0.1477 \\
(0.1294)\end{array}$ & $\begin{array}{l}-0.0806 \\
(0.1325)\end{array}$ \\
\hline \multicolumn{6}{|l|}{ Work and Income } \\
\hline Work for Pay & & & $\begin{array}{c}-0.4618 \\
(0.1220)\end{array}$ & $\begin{array}{c}-0.3423^{* *} \\
(0.1268)\end{array}$ & $\begin{array}{c}-0.2171 \\
(0.1296)\end{array}$ \\
\hline Log of Household & & & -0.0190 & -0.0141 & -0.0033 \\
\hline Income & & & $(0.0368)$ & $(0.0380)$ & $(0.0383)$ \\
\hline
\end{tabular}


Other Insurance

Employer-Sponsored

HI

Medicare

Medicaid

Self-Reported Health

(Omitted Group: Excellent)

Very Good

Good

Fair

Poor

Cognitive Measures

CIND or Dementia
$-1.0075^{* *}-1.0155^{* *}$

(0.1138) (0.1149)

$0.0972 \quad 0.0446$

(0.2222) (0.2236)

$-1.1213 * * \quad-1.1948 * *$

(0.3103) (0.3133)
0.0561

(0.1688)

$0.3565 * *$

(0.1555)

$0.8466 * *$

(0.1665)

$0.8127 * *$

(0.2231)

$-0.1668$

(0.1249)

\begin{tabular}{lccccc}
\hline Pseudo R-Squared & 0.0111 & 0.0316 & 0.0456 & 0.0808 & 0.0960 \\
Number of Observations & 2,299 & 2,299 & 2,299 & 2,299 & 2,299 \\
\hline \hline
\end{tabular}

Standard errors are reported in the parentheses.

$* *$ : $\mathrm{p}<0.05$ 
Table 2B: Likelihood of VA Services Usage, Veterans Eligible for VA

\begin{tabular}{|c|c|c|c|c|c|}
\hline \multirow[b]{2}{*}{ Dependent Variables } & \multicolumn{5}{|c|}{$\begin{array}{l}\text { Dependent variable=1 if the respondent is a VA user. } \\
\text { Coefficients on Logit Models }\end{array}$} \\
\hline & [1] & [2] & [3] & [4] & [5] \\
\hline \multicolumn{6}{|l|}{ Race and Gender } \\
\hline Black & $\begin{array}{c}0.4244^{* *} \\
(0.1811)\end{array}$ & $\begin{array}{c}0.3302 \\
(0.1956)\end{array}$ & $\begin{array}{c}0.3563 \\
(0.1988)\end{array}$ & $\begin{array}{c}0.4046 \\
(0.2068)\end{array}$ & $\begin{array}{c}0.3952 \\
(0.2084)\end{array}$ \\
\hline Female & & $\begin{array}{l}-0.7187 \\
(0.4414)\end{array}$ & $\begin{array}{l}-0.7244 \\
(0.4502)\end{array}$ & $\begin{array}{l}-0.7750 \\
(0.4666)\end{array}$ & $\begin{array}{l}-0.8040 \\
(0.4710)\end{array}$ \\
\hline \multicolumn{6}{|l|}{$\begin{array}{l}\text { Age } \\
\text { (Omitted Group: Age 60-64) }\end{array}$} \\
\hline Age $50-54$ & & $\begin{array}{l}-0.3741 \\
(0.4089)\end{array}$ & $\begin{array}{l}-0.3609 \\
(0.4162)\end{array}$ & $\begin{array}{l}-0.4915 \\
(0.4355)\end{array}$ & $\begin{array}{l}-0.5315 \\
(0.4411)\end{array}$ \\
\hline Age 55-59 & & $\begin{array}{l}-0.4689 \\
(0.3054)\end{array}$ & $\begin{array}{l}-0.4770 \\
(0.3135)\end{array}$ & $\begin{array}{l}-0.4785 \\
(0.3274)\end{array}$ & $\begin{array}{l}-0.4564 \\
(0.3319)\end{array}$ \\
\hline Age 65-69 & & $\begin{array}{l}-0.8923 * * \\
(0.2895)\end{array}$ & $\begin{array}{l}-0.9081^{* *} \\
(0.2931)\end{array}$ & $\begin{array}{c}-1.2975 * * \\
(0.3965)\end{array}$ & $\begin{array}{c}-1.1966 * * \\
(0.4002)\end{array}$ \\
\hline Age $70-74$ & & $\begin{array}{l}-0.3266 \\
(0.2616)\end{array}$ & $\begin{array}{l}-0.4057 \\
(0.2671)\end{array}$ & $\begin{array}{c}-0.7578 * * \\
(0.3822)\end{array}$ & $\begin{array}{l}-0.7130 \\
(0.3864)\end{array}$ \\
\hline Age $75+$ & & $\begin{array}{l}-0.3181 \\
(0.2235)\end{array}$ & $\begin{array}{l}-0.4811 \\
(0.2356)\end{array}$ & $\begin{array}{c}-0.7778 * * \\
(0.3578)\end{array}$ & $\begin{array}{l}-0.6623 \\
(0.3625)\end{array}$ \\
\hline \multicolumn{6}{|l|}{$\begin{array}{l}\text { Marital Status } \\
\text { (Omitted: Never Married) }\end{array}$} \\
\hline Married & & $\begin{array}{l}-0.1451 \\
(0.4201)\end{array}$ & $\begin{array}{c}0.0031 \\
(0.4399)\end{array}$ & $\begin{array}{c}0.2032 \\
(0.4582)\end{array}$ & $\begin{array}{c}0.1479 \\
(0.4648)\end{array}$ \\
\hline Partnered & & $\begin{array}{c}0.2848 \\
(0.5263)\end{array}$ & $\begin{array}{c}0.3940 \\
(0.5444)\end{array}$ & $\begin{array}{c}0.5082 \\
(0.5654)\end{array}$ & $\begin{array}{c}0.4374 \\
(0.5750)\end{array}$ \\
\hline Separated/Divorced & & $\begin{array}{c}0.1860 \\
(0.4575)\end{array}$ & $\begin{array}{c}0.1927 \\
(0.4716)\end{array}$ & $\begin{array}{c}0.2163 \\
(0.4883)\end{array}$ & $\begin{array}{c}0.1650 \\
(0.4959)\end{array}$ \\
\hline Widowed & & $\begin{array}{l}-0.3780 \\
(0.4730)\end{array}$ & $\begin{array}{l}-0.3464 \\
(0.4882)\end{array}$ & $\begin{array}{l}-0.1232 \\
(0.5076)\end{array}$ & $\begin{array}{l}-0.2273 \\
(0.5160)\end{array}$ \\
\hline \multicolumn{6}{|l|}{$\begin{array}{l}\text { Education } \\
\text { (Omitted Group: High School) }\end{array}$} \\
\hline Less than High School & & & $\begin{array}{c}0.7543^{* *} \\
(0.2288)\end{array}$ & $\begin{array}{c}0.7289 * * \\
(0.2372)\end{array}$ & $\begin{array}{c}0.6468 * * \\
(0.2368)\end{array}$ \\
\hline Some College & & & $\begin{array}{l}-0.0237 \\
(0.1795)\end{array}$ & $\begin{array}{l}-0.0313 \\
(0.1850)\end{array}$ & $\begin{array}{l}-0.0173 \\
(0.1871)\end{array}$ \\
\hline College or More & & & $\begin{array}{l}-0.2132 \\
(0.1883)\end{array}$ & $\begin{array}{l}-0.1983 \\
(0.1957)\end{array}$ & $\begin{array}{l}-0.1503 \\
(0.1990)\end{array}$ \\
\hline \multicolumn{6}{|l|}{ Work and Income } \\
\hline Work for Pay & & & $\begin{array}{l}-0.1767 \\
(0.1782)\end{array}$ & $\begin{array}{l}-0.0533 \\
(0.1872)\end{array}$ & $\begin{array}{c}0.0594 \\
(0.1931)\end{array}$ \\
\hline $\begin{array}{l}\text { Log of Household } \\
\text { Income }\end{array}$ & & & $\begin{array}{l}-0.0904 \\
(0.0623)\end{array}$ & $\begin{array}{l}-0.0731 \\
(0.0638)\end{array}$ & $\begin{array}{l}-0.0570 \\
(0.0647)\end{array}$ \\
\hline
\end{tabular}


Other Insurance

Employer-Sponsored

$-1.1950 * * \quad-1.2041 * *$

HI

(0.1662) (0.1681)

Medicare

$0.1556 \quad 0.0781$

Medicaid

(0.3418) (0.3463)

$-0.3752 \quad-0.3635$

(0.4382) (0.4473)

Self-Reported Health

(Omitted Group: Excellent)

Very Good

$-0.3187$

$(0.2568)$

Good

0.0030

(0.2317)

Fair

$0.5371^{* *}$

Poor

(0.2514)

0.1744

(0.3429)

Cognitive Measures

$-0.0544$

CIND or Dementia

(0.1831)

\begin{tabular}{lccccc}
\hline Pseudo R-Squared & 0.0045 & 0.0191 & 0.0392 & 0.0869 & 0.0989 \\
Number of Observations & 904 & 904 & 904 & 904 & 904 \\
\hline \hline
\end{tabular}

Standard errors are reported in the parentheses.

$* *$ : $\mathrm{p}<0.05$ 
Table 3A: Likelihood of Using VA Services Only, All Veterans

\begin{tabular}{|c|c|c|c|c|c|}
\hline \multirow[b]{2}{*}{ Dependent Variables } & \multicolumn{5}{|c|}{$\begin{array}{l}\text { Dependent variable }=1 \text { if the respondent uses VA services only. } \\
\text { Coefficients on Logit Models }\end{array}$} \\
\hline & [1] & {$[2]$} & [3] & [4] & [5] \\
\hline \multicolumn{6}{|l|}{ Race and Gender } \\
\hline Black & $\begin{array}{c}0.7547 * * \\
(0.1442)\end{array}$ & $\begin{array}{c}0.4803^{* *} \\
(0.1571)\end{array}$ & $\begin{array}{l}0.4415^{* *} \\
(0.1584)\end{array}$ & $\begin{array}{c}0.4492 * * \\
(0.1613)\end{array}$ & $\begin{array}{c}0.4773 * * \\
(0.1630)\end{array}$ \\
\hline Female & & $\begin{array}{l}-0.3990 \\
(0.2974)\end{array}$ & $\begin{array}{l}-0.3628 \\
(0.2970)\end{array}$ & $\begin{array}{l}-0.3747 \\
(0.3010)\end{array}$ & $\begin{array}{l}-0.3782 \\
(0.3031)\end{array}$ \\
\hline \multicolumn{6}{|l|}{$\begin{array}{l}\text { Age } \\
\text { (Omitted Group: Age 60-64) }\end{array}$} \\
\hline Age $50-54$ & & $\begin{array}{l}-0.0702 \\
(0.2851)\end{array}$ & $\begin{array}{c}0.0274 \\
(0.2899)\end{array}$ & $\begin{array}{c}0.0074 \\
(0.2935)\end{array}$ & $\begin{array}{c}0.0104 \\
(0.2953)\end{array}$ \\
\hline Age 55-59 & & $\begin{array}{l}-0.0983 \\
(0.2256)\end{array}$ & $\begin{array}{l}-0.0481 \\
(0.2296)\end{array}$ & $\begin{array}{l}-0.0647 \\
(0.2329)\end{array}$ & $\begin{array}{l}-0.0007 \\
(0.2351)\end{array}$ \\
\hline Age 65-69 & & $\begin{array}{c}-0.6488 * * \\
(0.2291)\end{array}$ & $\begin{array}{c}-0.7148 * * \\
(0.2318)\end{array}$ & $\begin{array}{c}-0.6113 * * \\
(0.2888)\end{array}$ & $\begin{array}{c}-0.5671^{* *} \\
(0.2899)\end{array}$ \\
\hline Age $70-74$ & & $\begin{array}{c}-0.3857 * * \\
(0.1948)\end{array}$ & $\begin{array}{c}-0.4914^{* *} \\
(0.1992)\end{array}$ & $\begin{array}{l}-0.3825 \\
(0.2727)\end{array}$ & $\begin{array}{l}-0.3878 \\
(0.2748)\end{array}$ \\
\hline Age $75+$ & & $\begin{array}{c}-0.4671^{* *} \\
(0.1733)\end{array}$ & $\begin{array}{c}-0.6311^{* *} \\
(0.1826)\end{array}$ & $\begin{array}{l}-0.5168 \\
(0.2585)\end{array}$ & $\begin{array}{c}-0.5390 * * \\
(0.2613)\end{array}$ \\
\hline \multicolumn{6}{|l|}{$\begin{array}{l}\text { Marital Status } \\
\text { (Omitted: Never Married) }\end{array}$} \\
\hline Married & & $\begin{array}{l}-0.5612 \\
(0.3062)\end{array}$ & $\begin{array}{l}-0.4121 \\
(0.3159)\end{array}$ & $\begin{array}{l}-0.3721 \\
(0.3190)\end{array}$ & $\begin{array}{l}-0.3231 \\
(0.3225)\end{array}$ \\
\hline Partnered & & $\begin{array}{c}0.2761 \\
(0.3616)\end{array}$ & $\begin{array}{c}0.3534 \\
(0.3716)\end{array}$ & $\begin{array}{c}0.3439 \\
(0.3745)\end{array}$ & $\begin{array}{c}0.3991 \\
(0.3782)\end{array}$ \\
\hline Separated/Divorced & & $\begin{array}{c}0.2302 \\
(0.3309)\end{array}$ & $\begin{array}{c}0.2748 \\
(0.3369)\end{array}$ & $\begin{array}{c}0.2680 \\
(0.3390)\end{array}$ & $\begin{array}{c}0.2733 \\
(0.3430)\end{array}$ \\
\hline Widowed & & $\begin{array}{l}-0.3383 \\
(0.3494)\end{array}$ & $\begin{array}{l}-0.3098 \\
(0.3551)\end{array}$ & $\begin{array}{l}-0.2410 \\
(0.3580)\end{array}$ & $\begin{array}{l}-0.1954 \\
(0.3619)\end{array}$ \\
\hline \multicolumn{6}{|l|}{$\begin{array}{l}\text { Education } \\
\text { (Omitted Group: High School) }\end{array}$} \\
\hline Less than High School & & & $\begin{array}{c}0.2387 \\
(0.1777)\end{array}$ & $\begin{array}{c}0.2404 \\
(0.1794)\end{array}$ & $\begin{array}{c}0.2311 \\
(0.1827)\end{array}$ \\
\hline Some College & & & $\begin{array}{l}-0.1010 \\
(0.1649)\end{array}$ & $\begin{array}{l}-0.1029 \\
(0.1482)\end{array}$ & $\begin{array}{l}-0.1031 \\
(0.1494)\end{array}$ \\
\hline College or More & & & $\begin{array}{c}-0.3174^{* *} \\
(0.1529)\end{array}$ & $\begin{array}{l}-0.2779 \\
(0.1545)\end{array}$ & $\begin{array}{l}-0.2977 \\
(0.1577)\end{array}$ \\
\hline \multicolumn{6}{|l|}{ Work and Income } \\
\hline Work for Pay & & & $\begin{array}{c}-0.3759 * * \\
(0.1445)\end{array}$ & $\begin{array}{c}-0.3310^{* *} \\
(0.1504)\end{array}$ & $\begin{array}{c}-0.3802 * * \\
(0.1539)\end{array}$ \\
\hline Log of Household & & & -0.0619 & -0.0575 & -0.0584 \\
\hline Income & & & $(0.0389)$ & $(0.0397)$ & $(0.0401)$ \\
\hline
\end{tabular}


Other Insurance

Employer-Sponsored $-0.6810 * * \quad-0.6942 * *$

HI

(0.1340) (0.1350)

Medicare

$-0.3242 \quad-0.3504$

Medicaid

(0.2407) (0.2410)

$-0.7211 * * \quad-0.6930 * *$

Self-Reported Health

(0.3431) (0.3469)

(Omitted Group: Excellent)

Very Good

$-0.7748 * *$

(0.1784)

Good

$-0.7022 * *$

(0.1635)

Fair

$-0.5728 * *$

Poor

(0.1780)

$-1.0188 * *$

(0.2754)

Cognitive Measures

0.0912

CIND or Dementia

$(0.1449)$

\begin{tabular}{lccccc}
\hline Pseudo R-Squared & 0.0119 & 0.0353 & 0.0477 & 0.0628 & 0.0754 \\
Number of Observations & 2,299 & 2,299 & 2,299 & 2,299 & 2,299 \\
\hline \hline
\end{tabular}

Standard errors are reported in the parentheses.

$* *: \mathrm{p}<0.05$ 
Table 3B: Likelihood of Using VA Services Only, Veterans Eligible for VA

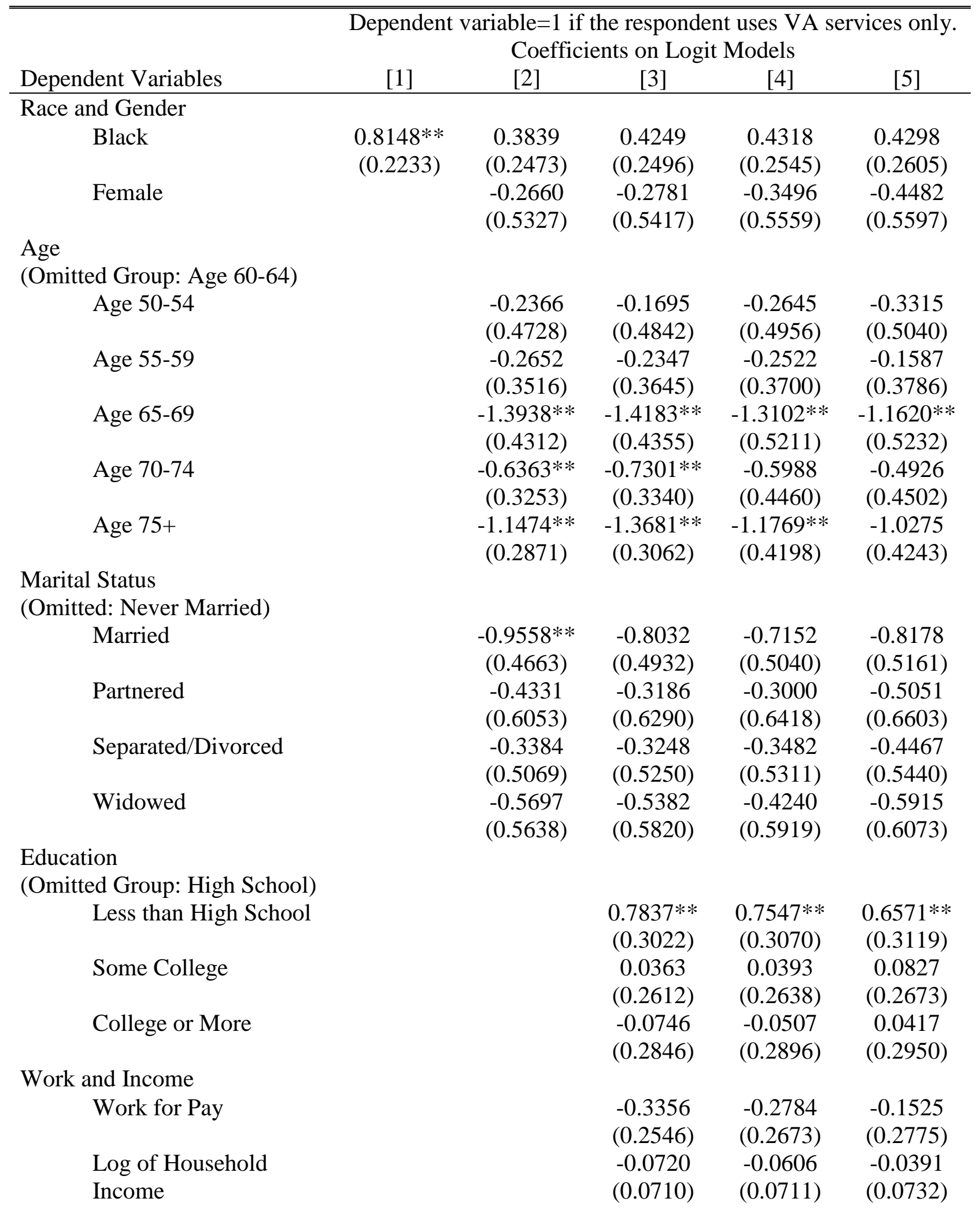


Other Insurance

Employer-Sponsored

$-0.8962 * * \quad-0.8860 * *$

HI

(0.2509) (0.2537)

Medicare

$-0.3820 \quad-0.5092$

Medicaid

(0.3950) (0.3971)

$-0.5159 \quad-0.4437$

(0.6208) (0.6319)

Self-Reported Health

(Omitted Group: Excellent)

Very Good

$-0.8441^{* *}$

(0.4144)

Good

0.0788

(0.3209)

Fair

0.4925

(0.3347)

Poor

$-0.1567$

(0.4860)

Cognitive Measures

0.0371

CIND or Dementia

$(0.2548)$

\begin{tabular}{lccccc}
\hline Pseudo R-Squared & 0.0167 & 0.0647 & 0.0831 & 0.1036 & 0.1243 \\
Number of Observations & 904 & 904 & 904 & 904 & 904 \\
\hline \hline
\end{tabular}

Standard errors are reported in the parentheses.

$* *: \mathrm{p}<0.05$ 
Table 3C: Likelihood of Using VA Services Only, VA User

\begin{tabular}{|c|c|c|c|c|c|}
\hline \multirow[b]{2}{*}{ Dependent Variables } & \multicolumn{5}{|c|}{$\begin{array}{l}\text { Dependent variable }=1 \text { if the respondent uses VA services only. } \\
\text { Coefficients on Logit Models }\end{array}$} \\
\hline & [1] & [2] & [3] & [4] & [5] \\
\hline \multicolumn{6}{|l|}{ Race and Gender } \\
\hline Black & $\begin{array}{c}0.5535 * * \\
(02715)\end{array}$ & $\begin{array}{c}0.0016 \\
(0.3143)\end{array}$ & $\begin{array}{c}0.0839 \\
(0.3197)\end{array}$ & $\begin{array}{c}0.0449 \\
(0.3228)\end{array}$ & $\begin{array}{c}0.0057 \\
(0.3257)\end{array}$ \\
\hline Female & & $\begin{array}{c}0.0590 \\
(0.7867)\end{array}$ & $\begin{array}{c}0.5853 \\
(0.7884)\end{array}$ & $\begin{array}{c}0.3959 \\
(0.7974)\end{array}$ & $\begin{array}{c}0.3451 \\
(0.8002)\end{array}$ \\
\hline \multicolumn{6}{|l|}{$\begin{array}{l}\text { Age } \\
\text { (Omitted Group: Age 60-64) }\end{array}$} \\
\hline Age $50-54$ & & $\begin{array}{l}-0.3225 \\
(0.6419)\end{array}$ & $\begin{array}{l}-0.3615 \\
(0.6483)\end{array}$ & $\begin{array}{l}-0.4158 \\
(0.6551)\end{array}$ & $\begin{array}{l}-0.4624 \\
(0.6673)\end{array}$ \\
\hline Age 55-59 & & $\begin{array}{c}0.2635 \\
(0.4679)\end{array}$ & $\begin{array}{c}0.2493 \\
(0.4809)\end{array}$ & $\begin{array}{c}0.1885 \\
(0.4855)\end{array}$ & $\begin{array}{c}0.1823 \\
(0.4912)\end{array}$ \\
\hline Age 65-69 & & $\begin{array}{l}-0.8577 \\
(0.5021)\end{array}$ & $\begin{array}{l}-0.8443 \\
(0.5059)\end{array}$ & $\begin{array}{l}-0.5068 \\
(0.6041)\end{array}$ & $\begin{array}{l}-0.4175 \\
(0.6069)\end{array}$ \\
\hline Age $70-74$ & & $\begin{array}{l}-0.5157 \\
(0.3929)\end{array}$ & $\begin{array}{l}-0.5762 \\
(0.4008)\end{array}$ & $\begin{array}{l}-0.1880 \\
(0.5161)\end{array}$ & $\begin{array}{l}-0.1459 \\
(0.5182)\end{array}$ \\
\hline Age $75+$ & & $\begin{array}{l}-1.2528 * * \\
(0.3546)\end{array}$ & $\begin{array}{l}-1.2982 * * \\
(0.3664)\end{array}$ & $\begin{array}{l}-0.9293 \\
(0.4874)\end{array}$ & $\begin{array}{l}-0.8094 \\
(0.4950)\end{array}$ \\
\hline \multicolumn{6}{|l|}{$\begin{array}{l}\text { Marital Status } \\
\text { (Omitted: Never Married) }\end{array}$} \\
\hline Married & & $\begin{array}{l}-0.7953 \\
(0.6740)\end{array}$ & $\begin{array}{l}-0.7465 \\
(0.6832)\end{array}$ & $\begin{array}{l}-0.7408 \\
(0.6850)\end{array}$ & $\begin{array}{l}-0.8781 \\
(0.7023)\end{array}$ \\
\hline Partnered & & $\begin{array}{l}-0.8143 \\
(0.8366)\end{array}$ & $\begin{array}{l}-0.8105 \\
(0.8492)\end{array}$ & $\begin{array}{l}-0.8147 \\
(0.8543)\end{array}$ & $\begin{array}{l}-1.0042 \\
(0.8728)\end{array}$ \\
\hline Separated/Divorced & & $\begin{array}{l}-0.3260 \\
(0.0790)\end{array}$ & $\begin{array}{l}-0.4190 \\
(0.7335)\end{array}$ & $\begin{array}{l}-0.4244 \\
(0.7380)\end{array}$ & $\begin{array}{l}-0.4776 \\
(0.7598)\end{array}$ \\
\hline Widowed & & $\begin{array}{l}-0.1077 \\
(0.7799)\end{array}$ & $\begin{array}{l}-0.1856 \\
(0.7897)\end{array}$ & $\begin{array}{l}-0.1576 \\
(0.7912)\end{array}$ & $\begin{array}{l}-0.3034 \\
(0.8090)\end{array}$ \\
\hline \multicolumn{6}{|l|}{$\begin{array}{l}\text { Education } \\
\text { (Omitted Group: High School) }\end{array}$} \\
\hline Less than High School & & & $\begin{array}{c}0.4460 \\
(0.3488)\end{array}$ & $\begin{array}{c}0.4793 \\
(0.3522)\end{array}$ & $\begin{array}{c}0.4351 \\
(0.3567)\end{array}$ \\
\hline Some College & & & $\begin{array}{c}0.0961 \\
(0.3097)\end{array}$ & $\begin{array}{c}0.0945 \\
(0.3126)\end{array}$ & $\begin{array}{c}0.1124 \\
(0.3163)\end{array}$ \\
\hline College or More & & & $\begin{array}{l}-0.1213 \\
(0.3464)\end{array}$ & $\begin{array}{l}-0.0926 \\
(0.3513)\end{array}$ & $\begin{array}{l}-0.0177 \\
(0.3582)\end{array}$ \\
\hline \multicolumn{6}{|l|}{ Work and Income } \\
\hline Work for Pay & & & $\begin{array}{l}-0.0167 \\
(0.2942)\end{array}$ & $\begin{array}{l}-0.0793 \\
(0.3082)\end{array}$ & $\begin{array}{l}-0.0072 \\
(0.3229)\end{array}$ \\
\hline $\begin{array}{l}\text { Log of Household } \\
\text { Income }\end{array}$ & & & $\begin{array}{l}-0.0938 \\
(0.1010)\end{array}$ & $\begin{array}{l}-0.0778 \\
(0.1027)\end{array}$ & $\begin{array}{l}-0.0607 \\
(0.1027)\end{array}$ \\
\hline
\end{tabular}


Other Insurance

Employer-Sponsored

$\begin{array}{ll}-0.2815 & -0.2595\end{array}$

HI

(0.3230) (0.3296)

Medicare

$-0.6194 \quad-0.6658$

Medicaid

(0.4662) (0.4693)

$-0.3838 \quad-0.3917$

Self-Reported Health

(0.7223) (0.7366)

(Omitted Group: Excellent)

Very Good

$-0.2332$

(0.5135)

Good

0.3697

(0.4069)

Fair

0.4596

$(0.4145)$

Poor

0.0687

(0.5739)

Cognitive Measures

$-0.0983$

CIND or Dementia

$(0.3008)$

\begin{tabular}{lccccc}
\hline Pseudo R-Squared & 0.0090 & 0.0719 & 0.0798 & 0.0856 & 0.0939 \\
Number of Observations & 364 & 364 & 364 & 364 & 364 \\
\hline \hline
\end{tabular}

Standard errors are reported in the parentheses.

$* *: \mathrm{p}<0.05$ 
Table 4: Quality of Care, VA vs Non-VA Services

\begin{tabular}{lccc}
\hline \hline & VA Better & Same & Non-VA Better \\
\hline VA User & $31.58 \%$ & $44.68 \%$ & $23.74 \%$ \\
Non-User & & & \\
Eligible & $5.31 \%$ & $44.06 \%$ & $50.63 \%$ \\
Not Eligible & $8.02 \%$ & $44.07 \%$ & $51.90 \%$ \\
\hline Total & $18.61 \%$ & $43.32 \%$ & $38.08 \%$ \\
\hline \hline
\end{tabular}

Note: $\mathrm{N}=1,354$

Table 5: Quality of Care, VA vs Non-VA Services; VA Users Only

\begin{tabular}{lccc}
\hline \hline & VA Better & Same & Non-VA Better \\
\hline Use VA Only & $58.15 \%$ & $33.44 \%$ & $8.41 \%$ \\
Use VA and Non-VA & $18.21 \%$ & $50.33 \%$ & $31.45 \%$ \\
\hline Total & $31.58 \%$ & $44.68 \%$ & $23.47 \%$ \\
\hline \hline
\end{tabular}

Note: $\mathrm{N}=679$

Table 6: Quality of Care, VA vs Non-VA Services; VA Users Only by Race

\begin{tabular}{lccc}
\hline \hline & VA Better & Same & Non-VA Better \\
\hline White & & & \\
Use VA Only & $56.40 \%$ & $35.04 \%$ & $8.55 \%$ \\
Use VA and Non-VA & $17.31 \%$ & $50.94 \%$ & $31.75 \%$ \\
\hline Total & $29.35 \%$ & $46.04 \%$ & $24.61 \%$ \\
\hline Black & & & \\
Use VA Only & $67.02 \%$ & $27.72 \%$ & $5.26 \%$ \\
Use VA and Non-VA & $21.59 \%$ & $44.89 \%$ & $33.52 \%$ \\
\hline Total & $43.94 \%$ & $36.44 \%$ & $19.62 \%$ \\
\hline \hline
\end{tabular}

Note: $\mathrm{N}=679$ 
Table 7A: Likelihood of VA Services Usage and Attitudes toward VA

\begin{tabular}{|c|c|c|c|}
\hline Dependent Variables & Pooled Sample & White & Black \\
\hline \multicolumn{4}{|l|}{ Race and Gender } \\
\hline Black & $\begin{array}{c}0.2791 \\
(0.1926)\end{array}$ & -- & -- \\
\hline Female & $\begin{array}{l}-0.2489 \\
(0.3575)\end{array}$ & $\begin{array}{l}-0.0655 \\
(0.4185)\end{array}$ & $\begin{array}{l}-1.2065 \\
(0.7813)\end{array}$ \\
\hline \multicolumn{4}{|l|}{$\begin{array}{l}\text { Age } \\
\text { (Omitted Group: Age 60-64) }\end{array}$} \\
\hline Age 50-54 & $\begin{array}{c}-1.0462 * * \\
(0.3553)\end{array}$ & $\begin{array}{c}-0.9845^{* *} \\
(0.4296)\end{array}$ & $\begin{array}{c}-1.4978^{* *} \\
(0.7393)\end{array}$ \\
\hline Age 55-59 & $\begin{array}{c}-0.8617 * * \\
(0.2985)\end{array}$ & $\begin{array}{c}-0.9694 * * \\
(0.3825)\end{array}$ & $\begin{array}{c}-.0841 \\
(0.5762)\end{array}$ \\
\hline Age 65-69 & $\begin{array}{l}-1.1336 * * \\
(0.3367)\end{array}$ & $\begin{array}{l}-1.1616^{* *} \\
(0.3739)\end{array}$ & $\begin{array}{c}-2.3231^{* *} \\
(1.0698)\end{array}$ \\
\hline Age 70-74 & $\begin{array}{c}-1.0767^{* *} \\
(0.3294)\end{array}$ & $\begin{array}{c}-1.0826^{* *} \\
(0.3717)\end{array}$ & $\begin{array}{l}-1.7679 \\
(0.9375)\end{array}$ \\
\hline Age $75+$ & $\begin{array}{l}-0.5277 \\
(0.3086)\end{array}$ & $\begin{array}{l}-0.5414 \\
(0.3481)\end{array}$ & $\begin{array}{l}-1.3026 \\
(0.8614)\end{array}$ \\
\hline \multicolumn{4}{|l|}{$\begin{array}{l}\text { Marital Status } \\
\text { (Omitted: Never Married) }\end{array}$} \\
\hline Married & $\begin{array}{c}0.3446 \\
(0.3849)\end{array}$ & $\begin{array}{c}0.5050 \\
(0.4555)\end{array}$ & $\begin{array}{l}-0.2721 \\
(0.8581)\end{array}$ \\
\hline Partnered & $\begin{array}{c}0.8005 \\
(0.4805)\end{array}$ & $\begin{array}{l}1.1642 * * \\
(0.5660)\end{array}$ & $\begin{array}{r}-0.9973 \\
(1.0714)\end{array}$ \\
\hline Separated/Divorced & $\begin{array}{c}0.9611 * * \\
(0.4172)\end{array}$ & $\begin{array}{c}0.9704 \\
(0.4992)\end{array}$ & $\begin{array}{c}0.7543 \\
(0.8946)\end{array}$ \\
\hline Widowed & $\begin{array}{l}-0.1205 \\
(0.4230)\end{array}$ & $\begin{array}{l}-0.0317 \\
(0.4940)\end{array}$ & $\begin{array}{r}-0.4049 \\
(1.0154)\end{array}$ \\
\hline \multicolumn{4}{|l|}{$\begin{array}{l}\text { Education } \\
\text { (Omitted Group: High School) }\end{array}$} \\
\hline Less than High School & $\begin{array}{c}0.3130 \\
(0.2127)\end{array}$ & $\begin{array}{c}0.3917 \\
(0.2246)\end{array}$ & $\begin{array}{l}-0.0801 \\
(0.7947)\end{array}$ \\
\hline Some College & $\begin{array}{c}0.0448 \\
(0.1672)\end{array}$ & $\begin{array}{c}0.0457 \\
(0.1846)\end{array}$ & $\begin{array}{c}0.1979 \\
(0.4862)\end{array}$ \\
\hline College or More & $\begin{array}{c}0.0099 \\
(0.1722)\end{array}$ & $\begin{array}{c}0.0330 \\
(0.1845)\end{array}$ & $\begin{array}{l}-0.3723 \\
(0.5601)\end{array}$ \\
\hline \multicolumn{4}{|l|}{ Work and Income } \\
\hline Work for Pay & $\begin{array}{l}-0.1126 \\
(0.1678)\end{array}$ & $\begin{array}{l}-0.1411 \\
(0.1850)\end{array}$ & $\begin{array}{c}0.4090 \\
(0.4950)\end{array}$ \\
\hline Log of Household Income & $\begin{array}{c}0.0043 \\
(0.0501)\end{array}$ & $\begin{array}{l}-0.0264 \\
(0.0568)\end{array}$ & $\begin{array}{c}0.0753 \\
(0.1372)\end{array}$ \\
\hline $\begin{array}{l}\text { Other Insurance } \\
\text { Employer-Sponsored HI }\end{array}$ & $\begin{array}{c}-0.9391 * * \\
(0.1417)\end{array}$ & $\begin{array}{c}-0.9519 * * \\
(0.1551)\end{array}$ & $\begin{array}{c}-1.1706^{* *} \\
(0.4240)\end{array}$ \\
\hline
\end{tabular}




$\begin{array}{lccc}\text { Medicare } & 0.0480 & 0.1558 & 0.2357 \\ \text { Medicaid } & (0.2886) & (0.3359) & (0.7446) \\ & -0.8081^{* *} & -0.2790 & -3.0416^{* *} \\ & (0.3985) & (0.4592) & (1.0406)\end{array}$

Self-Reported Health

(Omitted Group: Excellent)

$\begin{array}{lccc}\text { Very Good } & 0.2631 & 0.4455 & -0.6200 \\ \text { Good } & (0.2184) & (0.2356) & (0.6525) \\ & 0.3778 & 0.3582 & 0.8079 \\ \text { Fair } & (0.2021) & (0.2173) & (0.6242) \\ & 0.8366^{* *} & 0.8086^{* *} & 1.3515^{* *} \\ \text { Poor } & (0.2191) & (0.2365) & (0.6781) \\ & 1.0916^{* *} & 0.9624^{* *} & 2.6753^{* *} \\ & (0.2968) & (0.3156) & (1.1802)\end{array}$

Cognitive Measures

CIND or Dementia

$-0.4012 * *$

$-0.3880 * *$

$-0.4222$

(0.1611)

$(0.1735)$

(0.5172)

Attitudes toward VA

VA Better

$1.4151^{* *}$

$1.3052 * *$

$2.0853 * *$

(0.1978)

(0.2158)

(0.5667)

$-0.9450 * *$

$-1.0671 * *$

$-0.0841$

Non-VA Better

(0.1404)

(0.1524)

(0.4301)

\begin{tabular}{lccc}
\hline Pseudo R-Squared & 0.1834 & 0.1754 & 0.3266 \\
Number of Observations & 1,296 & 1,088 & 208 \\
\hline \hline
\end{tabular}

Coefficients are from logit models.

Standard errors are reported in the parentheses.

$* *$ : $\mathrm{p}<0.05$ 
Table 7B: Decomposition of Racial Gap in VA Services Usage

\begin{tabular}{lc}
\hline \hline Total Racial Gap & \\
$\mathrm{P}(\mathrm{VA}=1 \mid$ Black $)-\mathrm{P}(\mathrm{VA}=1 \mid$ White $)$ & 0.1003 \\
Unexplained & 0.0565 \\
Explained & 0.0438 \\
\hline $\begin{array}{l}\text { Can be attributed to racial difference in... } \\
\text { Gender }\end{array}$ & -0.0002 \\
Age & $0.0031)$ \\
Marital Status & -0.0031 \\
Education & $0.0259)$ \\
Work and Income & 0.0128 \\
& $(0.0071)$ \\
Health & -0.0033 \\
& $(0.0039)$ \\
Other Insurance & -0.0031 \\
Attitudes toward Quality of VA Services & $(0.0054)$ \\
& $0.0058^{* *}$ \\
& $(0.0027)$ \\
\hline \hline
\end{tabular}

$* *: \mathrm{p}<0.05$ 
Table 8A: Likelihood of VA Services Usage and Attitudes toward VA, Eligible Veterans

\begin{tabular}{|c|c|c|c|}
\hline Dependent Variables & Pooled Sample & White & Black \\
\hline \multicolumn{4}{|l|}{ Race and Gender } \\
\hline Black & $\begin{array}{c}0.0773 \\
(0.2560)\end{array}$ & -- & -- \\
\hline Female & $\begin{array}{c}-1.3157 * * \\
(0.6070)\end{array}$ & $\begin{array}{l}-1.0703 \\
(0.6722)\end{array}$ & $\begin{array}{c}-3.0601 \\
(1.6550)\end{array}$ \\
\hline \multicolumn{4}{|l|}{$\begin{array}{l}\text { Age } \\
\text { (Omitted Group: Age 60-64) }\end{array}$} \\
\hline Age $50-54$ & $\begin{array}{l}-0.4528 \\
(0.5253)\end{array}$ & $\begin{array}{l}-0.2315 \\
(0.6801)\end{array}$ & $\begin{array}{c}-1.4316^{* *} \\
(1.0423)\end{array}$ \\
\hline Age 55-59 & $\begin{array}{l}-0.7848 \\
(0.4260)\end{array}$ & $\begin{array}{l}-1.0934 \\
(0.5693)\end{array}$ & $\begin{array}{l}-0.5928 \\
(0.9223)\end{array}$ \\
\hline Age 65-69 & $\begin{array}{l}-1.1900^{* *} \\
(0.5098)\end{array}$ & $\begin{array}{c}-1.5250 * * \\
(0.6296)\end{array}$ & $\begin{array}{l}-1.5624 \\
(1.2935)\end{array}$ \\
\hline Age 70-74 & $\begin{array}{c}-1.0356^{* *} \\
(0.4942)\end{array}$ & $\begin{array}{c}-1.2111^{* *} \\
(0.6191)\end{array}$ & $\begin{array}{r}-1.2245 \\
(1.1434)\end{array}$ \\
\hline Age $75+$ & $\begin{array}{l}-0.6004 \\
(0.4604)\end{array}$ & $\begin{array}{l}-0.8013 \\
(0.5745)\end{array}$ & $\begin{array}{l}-1.1040 \\
(1.0763)\end{array}$ \\
\hline \multicolumn{4}{|l|}{$\begin{array}{l}\text { Marital Status } \\
\text { (Omitted: Never Married) }\end{array}$} \\
\hline Married & $\begin{array}{c}0.3808 \\
(0.5632)\end{array}$ & $\begin{array}{c}0.4476 \\
(0.7272)\end{array}$ & $\begin{array}{c}0.4950 \\
(1.2517)\end{array}$ \\
\hline Partnered & $\begin{array}{c}0.6460 \\
(0.7126)\end{array}$ & $\begin{array}{c}1.1329 \\
(0.9281)\end{array}$ & $\begin{array}{l}-1.0753 \\
(1.4848)\end{array}$ \\
\hline Separated/Divorced & $\begin{array}{c}0.6732 \\
(0.6109)\end{array}$ & $\begin{array}{c}0.5916 \\
(0.8019)\end{array}$ & $\begin{array}{c}0.6902 \\
(1.2598)\end{array}$ \\
\hline Widowed & $\begin{array}{l}-0.2601 \\
(0.6214)\end{array}$ & $\begin{array}{l}-0.1789 \\
(0.7830)\end{array}$ & $\begin{array}{l}-1.4340 \\
(1.8573)\end{array}$ \\
\hline \multicolumn{4}{|l|}{$\begin{array}{l}\text { Education } \\
\text { (Omitted Group: High School) }\end{array}$} \\
\hline Less than High School & $\begin{array}{c}0.5111 \\
(0.3043)\end{array}$ & $\begin{array}{l}0.8093 * * \\
(0.3362)\end{array}$ & $\begin{array}{l}-0.8082 \\
(1.1218)\end{array}$ \\
\hline Some College & $\begin{array}{l}-0.3497 \\
(0.2329)\end{array}$ & $\begin{array}{l}-0.2860 \\
(0.2637)\end{array}$ & $\begin{array}{c}-0.4198 \\
(0.6580)\end{array}$ \\
\hline College or More & $\begin{array}{l}-0.3062 \\
(0.2434)\end{array}$ & $\begin{array}{c}-0.2043 \\
(0.2651)\end{array}$ & $\begin{array}{c}-0.4073 \\
(0.8920)\end{array}$ \\
\hline \multicolumn{4}{|l|}{ Work and Income } \\
\hline Work for Pay & $\begin{array}{c}0.0953 \\
(0.2419)\end{array}$ & $\begin{array}{c}0.0575 \\
(0.2709)\end{array}$ & $\begin{array}{c}0.2917 \\
(0.7688)\end{array}$ \\
\hline Log of Household Income & $\begin{array}{l}-0.0035 \\
(0.0732)\end{array}$ & $\begin{array}{l}-0.0987 \\
(0.0864)\end{array}$ & $\begin{array}{c}0.2510 \\
(0.3023)\end{array}$ \\
\hline $\begin{array}{l}\text { Other Insurance } \\
\text { Employer-Sponsored HI }\end{array}$ & $\begin{array}{c}-1.0692 * * \\
(0.2022)\end{array}$ & $\begin{array}{c}-1.1269 * * \\
(0.2308)\end{array}$ & $\begin{array}{c}-1.2243 * * \\
(0.5757)\end{array}$ \\
\hline
\end{tabular}




$\begin{array}{lccc}\text { Medicare } & 0.1744 & 0.4818 & 0.0328 \\ \text { Medicaid } & (0.4444) & (0.5847) & (1.0130) \\ & -0.5869 & -0.0460 & -3.6069 \\ (0.5324) & (0.5896) & (1.8941)\end{array}$

Self-Reported Health

(Omitted Group: Excellent)

\begin{tabular}{lccc} 
Very Good & -0.2421 & 0.1022 & $-1.8360 * *$ \\
Good & $(0.3183)$ & $(0.3563)$ & $(0.8980)$ \\
\multirow{2}{*}{ Fair } & -0.0962 & -0.0645 & 0.0861 \\
& $(0.2923)$ & $(0.3216)$ & $(0.8315)$ \\
Poor & 0.5375 & 0.5305 & 0.4398 \\
& $(0.3157)$ & $(0.3561)$ & $(0.8651)$ \\
& 0.4782 & 0.4651 & 0.8123 \\
& $(0.4306)$ & $(0.4710)$ & $(1.4585)$
\end{tabular}

Cognitive Measures

CIND or Dementia

$\begin{array}{lcc}-0.4196 & -0.4451 & 0.0005 \\ (0.2302) & (0.2567) & (0.6532)\end{array}$

Attitudes toward VA

\begin{tabular}{cccc}
\multicolumn{1}{c}{ VA Better } & $1.9490^{* *}$ & $1.7982^{* *}$ & $3.2086^{* *}$ \\
& $(0.3020)$ & $(0.3361)$ & $(0.9129)$ \\
Non-VA Better & $-0.9397^{* *}$ & $-1.1012^{* *}$ & 0.0361 \\
& $(0.1976)$ & $(0.2194)$ & $(0.5931)$ \\
\hline Pseudo R-Squared & 0.3156 & 0.2188 & 0.3800 \\
Number of Observations & 692 & 564 & 128 \\
\hline \hline
\end{tabular}

Coefficients are from logit models.

Standard errors are reported in the parentheses.

**: $\mathrm{p}<0.05$ 
Table 8B: Decomposition of Racial Gap in VA Services Usage, Eligible Veterans

\begin{tabular}{lc}
\hline \hline Total Racial Gap & \\
$\mathrm{P}(\mathrm{VA}=1 \mid$ Black $)-\mathrm{P}(\mathrm{VA}=1 \mid$ White $)$ & 0.0529 \\
Unexplained & 0.0184 \\
Explained & 0.0345 \\
\hline $\begin{array}{l}\text { Can be attributed to racial difference in... } \\
\text { Gender }\end{array}$ & 0.0005 \\
Age & $0.0017)$ \\
Marital Status & 0.0093 \\
& $0.0339)$ \\
Education & 0.0125 \\
Work and Income & $(0.0125)$ \\
Health & -0.0111 \\
& $0.0059)$ \\
Other Insurance & 0.0028 \\
& $(0.0090)$ \\
Attitudes toward Quality of VA Services & 0.0056 \\
& $(0.0047)$ \\
\hline \hline
\end{tabular}

$* *: \mathrm{p}<0.05$ 